\title{
THE CONTENT OF SOME TECHNOLOGICAL QUALITY COMPONENTS AND MYCOTOXINS IN GRAIN OF FOUR CULTIVARS OF SPRING WHEAT DEPENDING ON GRAIN STORAGE TIME AFTER HARVEST
}

\author{
Cezary A. Kwiatkowski ${ }^{1}$, Elzbieta Harasim ${ }^{1, *}$ Antoni Mis ${ }^{2}$, Malgorzata Haliniarz ${ }^{1}$, Jaroslaw \\ Mazurkiewicz $^{3}$ and Marta Tomczyńska-Mleko ${ }^{4}$
}

\author{
${ }^{1}$ Department of Herbology and Plant Cultivation Techniques, University of Life \\ Sciences, Poland; ${ }^{2}$ Institute of Agrophysics in Lublin, Polish Academy of Sciences, Poland; \\ ${ }^{3}$ Department of Analysis and Evaluation of Food Quality, University of Life Sciences, \\ Poland; ${ }^{4}$ Institute of Plant Genetics, Breeding and Biotechnology, University of Life Sciences, Poland. \\ "Corresponding author's e-mail: elzbieta.harasim@up.lublin.pl
}

\begin{abstract}
The aim of this study was to determine the effect of three grain storage times and the cultivar factor on some parameters used in commodity analysis of spring wheat grains. A field experiment was conducted in Czeslawice (Poland) using the split-plot method in 3 replicates in $27 \mathrm{~m}^{2}$ plots. This paper presents the effect of storage time (3,15, 27 months) of grain of four spring wheat cultivars ('Korynta', 'Monsun', 'Tybalt', 'Zadra') on some technological quality characteristics. After harvest, the grains were dried to the moisture content $14 \%$ and subsequently stockpiled in a warehouse. It was observed that grains can be stored for a period of even two years with no risk if all the grain storage rules are followed. Short- and long-term grain storage (3-27 months) resulted in satisfactory values of the grain quality characteristics like grain moisture, protein content, and grain hardness index. The storage of grain did not affect negatively grain contamination with mycotoxins. No significant differences were observed in the response of the cultivars studied (grain moisture content, protein content, grain hardness index) to grain storage time. Significant differences among the cultivars were observed in the grain hardness index after 3-month storage. It was also noted that the cultivars 'Korynta' and 'Tybalt' were characterized by lower susceptibility to contamination with mycotoxins than cvs. 'Zadra' and 'Monsun'. The results obtained in this study are a good indicator for cereal producers who store grains for a period of even two years, thus becoming independent of changing price conditions in the cereals market and the changing demand for and supply of animal feed and bread grain across other countries.
\end{abstract}

Keywords: Cereals, grain storage, Fusarium mycotoxin, mold fungi, spring wheat, price fluctuation.

\section{INTRODUCTION}

In the literature of the subject, there is a shortage of studies on the impact of storage time of wheat grain on its technological quality. Therefore, the results of this research fill the gap in this area. It is an innovative study both in Poland and in other countries. It shows that long-term storage (15-27 months) of wheat grain in warehouses is possible without deleterious quality changes in grain (grain moisture, grain hardness, mycotoxin content). Raza et al. (2010) reported the importance of storage method and time for grain quality. The conditions in which cereal grain is stored and kept have a considerable effect on its technological quality. As a result of improper grain storage, a number of negative changes often occur, such as an increase in grain moisture content and at the same time a decrease in grain protein content and decreased grain hardness (Kibar, 2016). This in turn creates favorable conditions for contamination of grain with mycotoxins. In such case, grain of poor quality is unsuitable for baking purposes (bread grain), but also for animal feed purposes (a lower nutritional value for animals, a high content of mycotoxins). Moreover, a decrease in the grain hardness index, an increased moisture content, and infection by pathogenic fungi all cause difficulties with the transport of grain, especially for long distances (Edwards, 2004; Chelowski et al., 2012; Kumar et al., 2017).

Mycotoxins are products of metabolism of mold fungi and occur both under conventional and organic cereal production systems. Mycotoxins have always accompanied humans and cannot be eliminated completely. We divide them into those produced by cereal pathogenic fungi of the genus Fusarium, which infect ears of cereals during field cultivation, and those produced during storage of plant materials under improper storage conditions. Contamination of cereal grains with mycotoxins is a serious problem of agricultural production in many countries (Goswami and Kistler, 2004; Fernandez et al., 2007).

Taking into account the above considerations, the study hypothesized that favorable technological quality parameters can be obtained, both under short-term grain storage (3 months after harvest) and long-term storage (15-27 months), on the condition that proper spring wheat storage conditions 
(temperature, humidity, and irradiation) are observed. An assumption was also made that the individual spring wheat cultivars can show certain variations in the grain quality characteristics as affected by storage time (they differ in the response strength to storage duration). A positive verification of the above hypotheses could be of great importance for agricultural practice and the processing industry. As a result of excess cereal production or price fluctuations in the markets in many countries, grain must often be stored for a long time or transported to other countries.

The aim of this study was to determine the effect of three grain storage times and the cultivar factor on some parameters used in commodity analysis of spring wheat grain.

\section{MATERIALS AND METHODS}

Experimental site and experimental design: The field experiment was conducted in 2012-2014 in Czesławice (Lubelskie Voivodeship, Poland). The experiment was set up using the split-plot method in three replications. The area of a single plot was $27 \mathrm{~m}^{2}$. The experiment was established on grey-brown podzolic soil derived from loess classified as good wheat soil complex. Sugar beet was the previous crop for spring wheat.

The study included the following factors: I. Grain storage time after harvest for the individual spring wheat cultivars: 27 months, 15 months, 3 months; II. Spring wheat cultivars: Korynta, Monsun, Tybalt, and Zadra.

Agronomic practices: Mineral fertilization, adjusted to high soil macronutrient availability, was as follows on a per hectare basis: $\mathrm{N}-60 \mathrm{~kg}, \mathrm{P}_{2} \mathrm{O}_{5}-50 \mathrm{~kg}, \mathrm{~K}_{2} \mathrm{O}-80 \mathrm{~kg}$. The following crop protection chemicals were used for all the spring wheat cultivars: herbicide Chwastox Turbo 340 SL (MCPA + dicamba) + Puma Uniwersal 069 EW (fenoxapropP-ethyl + mefenpyr-diethyl) $-2.0+1.01 \mathrm{ha}^{-1}$, growth retardant Cerone $480 \mathrm{SL}$ (ethephon) - $1.0 \mathrm{l} \mathrm{ha}^{-1}$, fungicide Alert $375 \mathrm{SC}$ (flusilazole + carbendazim) at a rate of $1.01 \mathrm{ha}^{-}$ 1. The crop protection agents were applied using a field sprayer under a pressure of $0.25 \mathrm{MPa}$, at times in accordance with the recommendations of the Institute of Plant Protection - State Research Institute in Poznan, Poland.

In the period 2012-2014, spring wheat was sown in the second 10 days of April and harvested in the first 10 days of August (at full grain maturity).

Treatments: Subsequently, the grain was stored in a granary (a flat storage warehouse) in piles on neutral substrate in the temperature range of $10-15^{\circ} \mathrm{C}$. During the storage period, the wheat grain was separated from direct light (sunlight, artificial illumination) by using special blinds and also aerated (mixed) periodically, thus preventing its overheating. The storage warehouse was equipped with the following equipment: a fan and a blower, a device supplying compressed air from the fan to the bulk grain, a perforated floor and perforated ventilation ducts, a measuring and control instrument (air flow rate, temperature, moisture) (Rudzinski, 2011; Kibar, 2016). The determination of the grain content of chemical components, mycotoxin content, and physical characteristics (grain hardness) was made twice: (I) after harvest of spring wheat (August 18, 2012; August 15, 2013; August 16, 2014) and (II) at the end of storage (November 15-18, 2014). Effects of the harvest year-storage time interactions on grain quality parameters were estimated by calculating the absolute differences (+/-) between values of the parameters determined at the initial (I) and the end (II) of storage.

Chemical and physical analyses: The protein and moisture content in spring wheat grain was determined by the NIR (near infrared) method (PN-EN-ISO 20483, 2014), an Inframatic 9500 grain analyzer (Perten Instruments). The grain hardness index was determined by the Single Kernel Characterization System (SKCS), model 4100 (Perten Instruments). The grain mycotoxin content was determined by high performance liquid chromatography HPLC (SYKAM) using different types of detectors (fluorescence, photodiode, refractometric) in order to detect specific types of mycotoxins (Commission Regulation (EC) No 1126/2007, Chelkowski et al., 2012).

Weather conditions: Weather conditions during the growing season of spring wheat in particular years are listed in Table 1. The total rainfall during the 2012 growing season of spring wheat was lower than the long-term mean, in 2013 it exceeded the mean value by $50.0 \mathrm{~mm}$, while in 2014 it was almost identical as the long-term mean.

Table 1. Rainfall and air temperature in the growing seasons during the period 2012-2014 as compared to the long-term means (1974-2003) according to the Meteorological Station at Czesławice.

\begin{tabular}{|c|c|c|c|c|c|c|}
\hline \multirow[t]{3}{*}{ Year } & \multicolumn{5}{|c|}{ Month } & \multirow[t]{3}{*}{ Total } \\
\hline & IV & V & VI & VII & VIII & \\
\hline & \multicolumn{5}{|c|}{ Rainfall (mm) } & \\
\hline 2012 & 25.7 & 56.9 & 23.6 & 26.8 & 160.0 & 293.0 \\
\hline 2013 & 20.4 & 83.6 & 82.4 & 99.4 & 78.5 & 364.3 \\
\hline 2014 & 44.6 & 70.8 & 40.6 & 93.0 & 61.5 & 310.5 \\
\hline $\begin{array}{l}\text { Mean for } \\
1974-2003\end{array}$ & 40.4 & 53.8 & 73.6 & 80.1 & 66.4 & 314.3 \\
\hline Year & \multicolumn{5}{|c|}{ Temperature $\left({ }^{\circ} \mathrm{C}\right)$} & Mean \\
\hline 2012 & 8.8 & 13.4 & 16.9 & 20.8 & 18.5 & 15.7 \\
\hline 2013 & 8.2 & 15.0 & 17.2 & 19.4 & 18.7 & 15.7 \\
\hline 2014 & 9.0 & 13.5 & 17.4 & 18.3 & 19.0 & 15.5 \\
\hline $\begin{array}{l}\text { Mean for } \\
1974-2003\end{array}$ & 7.7 & 13.7 & 16.5 & 18.0 & 17.4 & 14.7 \\
\hline
\end{tabular}

A period of drought before the harvest of spring wheat (JuneJuly 2012) and at the same time intense rainfall in August 2012, which impeded harvesting of the crop, should be noted. During the period 2013-2014, the amount of rainfall in the months June-August was similar to the long-term mean. The 
average air temperatures in all the growing seasons and during the harvest of spring wheat grain were very similar to one another, but at the same time they were higher than the longterm mean.

It must be noted, that in addition to the storage time also different weather conditions during the growth and harvest of the crops in the particular years (Table 1) might have indirectly affected the dynamics of quality changes in stored grain.

Statistical analysis

The obtained results were statistically analyzed using Statistica PL, while analysis of variance was performed using Tukey's test at a significance level of $P=0.05$. The significance of differences in changes in the evaluated parameters was assessed based on the $95 \%$ confidence intervals of the means, while the relationship between storage time and changes in the evaluated parameters by linear regression analysis.

\section{RESULTS}

Characteristics of the initial condition of grain in the harvest year (beginning of storage) of the individual spring wheat cultivars: In the case of the cultivars 'Korynta' and 'Tybalt', the initial grain moisture content recorded in the individual harvest years $(2012,2013,2014)$ was at a similar, statistically insignificant level. On the other hand, grain of cvs. 'Monsun' and 'Zadra' harvested in 2014 was characterized by a significantly higher moisture content (by respectively 0.61 and 0.59 p.p. (percentage point)) compared to that harvested in the years 2012-2013 (Table 2).

Depending on the harvest year, the protein content in spring wheat grain significantly varied only in the case of $\mathrm{cv}$. 'Korynta' (a significantly lower content of this component was found in grain harvested in 2012 relative to the years 2013-2014). However, grain protein content was strictly related to the cultivar factor $-\mathrm{cv}$. 'Korynta' was characterized by the highest grain protein content $(13.38-14.17 \%)$ in comparison to the other cultivars (Table 2).

The grain hardness index did not differ significantly in the individual harvest years. But in each harvest year, cvs. 'Korynta' and 'Tybalt' were found to exhibit significantly greater grain hardness compared to grain of cvs. 'Monsun' and 'Zadra' (Table 2).

The initial mycotoxin content in spring wheat grain determined immediately after harvest showed significant variations in the case of deoxynivalenol (DON) and nivalenol (NIV); it was significantly higher in grain harvested in 2012 than in the years 2013-2014. Regardless of the harvest year, cvs. 'Monsun' and 'Zadra' were found to exhibit higher

Table 2. Grain quality at the beginning of storage in relation to wheat cultivar and harvest year.

\begin{tabular}{l} 
Grain quality \\
\cline { 2 - 11 } \\
\cline { 2 - 11 }
\end{tabular}

Table 3. Mycotoxin concentration ( $\mu \mathrm{g} \mathrm{kg}^{-1}$ grain) at the beginning of storage in relation to wheat cultivar and harvest year.

\begin{tabular}{|c|c|c|c|c|c|}
\hline \multirow[t]{2}{*}{ Harvest year } & \multicolumn{5}{|c|}{ Mycotoxins } \\
\hline & DON* $^{*}$ & NIV & T2 & HT2 & ZEA \\
\hline 2012 & 28.8 & 3.43 & 1.16 & 2.78 & 7.17 \\
\hline 2013 & 23.3 & 3.04 & 1.10 & 2.75 & 7.12 \\
\hline 2014 & 22.9 & 2.84 & 1.08 & 2,63 & 7.09 \\
\hline $\operatorname{LSD}_{(0.05)}$ & 4.32 & 0.366 & $\mathrm{NS}^{* *}$ & NS & NS \\
\hline \multicolumn{6}{|l|}{ Wheat cultivars } \\
\hline Korynta & 22.9 & 2.81 & 1.05 & 2.61 & 6.82 \\
\hline Monsun & 27.5 & 3.32 & 1.09 & 2.76 & 7.17 \\
\hline Tybalt & 23.2 & 2.86 & 1.06 & 2.63 & 6.86 \\
\hline Zadra & 28.0 & 3.43 & 1.12 & 2.77 & 7.21 \\
\hline $\operatorname{LSD}_{(0.05)}$ & 4.22 & 0.398 & NS & NS & 0.302 \\
\hline
\end{tabular}

"Explanation: DON - deoxynivalenol, ZEA - zearalenone, NIV - nivalenol, T2 and HT2 - trichothecenes.

**NS - non-statistically significant difference 
susceptibility to fungal infection and thus a significantly higher content of deoxynivalenol (DON), nivalenol (NIV) and zearalenone (ZEA) mycotoxins in their grain than cvs. 'Korynta' and 'Tybalt' (Table 3).

Characteristics of the technological quality of grain of spring wheat cultivars after different storage periods:

Grain moisture content: Storage time did not affect significantly the moisture content of spring wheat grain. The study did not also find any changes in grain moisture content as affected by the cultivar factor. Significant differences were noted for the interaction between storage time and cultivar (higher grain moisture content of the cultivars 'Monsun' and 'Zadra' after 3-month storage time) (Table 4).

A significant negative correlation was found between grain storage time and grain moisture content ( $\mathrm{r}$ from -0.87 to 0.90 ). The linear regression equations show that $\mathrm{cv}$. 'Monsum' was characterized by the highest stability of the parameter in question; in the case of this cultivar, the grain moisture loss rate during storage was slowest and averaged $0.016 \%$ per month. The value of the coefficient of determination (R2) indicates that as much as $82 \%$ of the variation in grain moisture content is explained by this model (Table 7).

Grain protein content: Storage time did not affect significantly the protein content of spring wheat grain. Among the cultivars compared, cv. 'Korynta' was characterized by the highest (statistically proven) protein content. The significantly highest protein content in $\mathrm{cv}$. 'Korynta' grain (14.24\%) was found after 3 -month grain storage (Table 5). Similarly, as in the case of moisture content, a significant negative relationship was also found between storage time and protein content ( $\mathrm{r}$ from -0.89 to 0.95 ). The linear regression equations show that the lowest decline in protein content occurred in grain of cv. 'Tybalt', on average $0.006 \%$ per month (Table 7 ).

Grain hardness index: The hardness index of spring wheat

Table 4. Moisture content of spring wheat grain (\%).

\begin{tabular}{|c|c|c|c|c|c|c|c|}
\hline \multirow[t]{2}{*}{ Cultivar } & \multicolumn{6}{|c|}{$\begin{array}{l}\text { Storage time after harvest (months) and the moisture different (MD) of the results for } \\
\text { the individual storage times as determined after grain harvest in a particular year }\end{array}$} & \multirow[t]{2}{*}{ Mean } \\
\hline & 27 & MD +/- & 15 & MD +/- & 3 & $\mathrm{MD}+/-$ & \\
\hline Korynta & 13.36 & -0.73 & 13.48 & -0.24 & 13.81 & -0.21 & 13.55 \\
\hline Monsun & 13.42 & -0.62 & 13.57 & -0.30 & 14.32 & -0.24 & 13.77 \\
\hline Tybalt & 13.38 & -0.70 & 13.50 & -0.23 & 13.87 & -0.19 & 13.58 \\
\hline Zadra & 13.39 & -0.69 & 13.55 & -0.28 & 14.24 & -0.25 & 13.72 \\
\hline Mean & 13.39 & -0.68 & 13.52 & -0.26 & 14.06 & -0.22 & - \\
\hline
\end{tabular}

Table 5. Total protein content in spring wheat grain (\%).

\begin{tabular}{lccccccc}
\hline Cultivar & \multicolumn{2}{c}{$\begin{array}{l}\text { Storage time after harvest (months) and the protein different (PD) of the results for } \\
\text { the individual storage times as determined after grain harvest in a particular year }\end{array}$} & \multirow{2}{*}{ Mean } \\
\cline { 2 - 6 } & $\mathbf{2 7}$ & $\mathbf{P D}+/-$ & $\mathbf{1 5}$ & $\mathbf{P D}+/-$ & $\mathbf{3}$ & $\mathbf{P D}+/-$ & \\
\hline Korynta & $13.24 \mathrm{a}^{*}$ & -0.14 & $13.79 \mathrm{a}$ & -0.09 & $14.24 \mathrm{~b}$ & +0.07 & $13.76 \mathrm{~A}^{* *}$ \\
Monsun & $11.98 \mathrm{a}$ & -0.17 & $12.16 \mathrm{a}$ & -0.13 & $12.53 \mathrm{a}$ & +0.03 & $12.22 \mathrm{~B}$ \\
Tybalt & $12.33 \mathrm{a}$ & -0.11 & $12.41 \mathrm{a}$ & -0.08 & $12.88 \mathrm{a}$ & +0.04 & $12.54 \mathrm{~B}$ \\
Zadra & $11.74 \mathrm{a}$ & -0.15 & $11.88 \mathrm{a}$ & -0.11 & $12.10 \mathrm{a}$ & +0.02 & $11.90 \mathrm{~B}$ \\
Mean & $12.32 \mathrm{a}$ & -0.14 & $12.56 \mathrm{a}$ & -0.10 & $12.94 \mathrm{a}$ & +0.04 & - \\
\hline
\end{tabular}

$\operatorname{LSD}_{(\mathrm{p}=0.05)}$ for storage time after harvest $=\mathrm{NS}$; for cultivars $=1.203$; for interaction: storage time after harvest $\times$ cultivars $=0.442$

*NS - non-statistically significant difference

Table 6. Hardness index of spring wheat grain.

\begin{tabular}{|c|c|c|c|c|c|c|c|}
\hline \multirow[t]{2}{*}{ Cultivar } & \multicolumn{6}{|c|}{$\begin{array}{l}\text { Storage time after harvest (months) and the hardness index different (HD) of the results } \\
\text { for the individual storage times as determined after grain harvest in a particular year }\end{array}$} & \multirow[t]{2}{*}{ Mean } \\
\hline & 27 & HD +/- & 15 & HD +/- & 3 & HD +/- & \\
\hline Korynta & 65.22 & +0.13 & 65.31 & +0.06 & 65.44 & +0.07 & 65.32 \\
\hline Monsun & 64.87 & +0.11 & 64.91 & +0.04 & 64.98 & +0.04 & 64.92 \\
\hline Tybalt & 65.16 & +0.14 & 65.28 & +0.05 & 65.35 & +0.06 & 65.26 \\
\hline Zadra & 64.83 & +0.11 & 64.88 & +0.04 & 65.02 & +0.03 & 64.91 \\
\hline Mean & 65.02 & +0.12 & 65.09 & +0.05 & 65.19 & +0.05 & - \\
\hline
\end{tabular}


grain did not differ significantly as affected by different grain storage times after harvest (3-27 months) and ranged 65.0265.19. No statistically confirmed differences were found in the grain hardness index under the influence of the cultivar factor, either (Table 6).

A significant positive relationship was revealed between grain storage time and hardness index ( $\mathrm{r}$ from 0.75 to 0.86 ). The regression equation indicates that grain hardness increased slowest in cv. 'Korynta', on average by $0.0024 /$ month, but only $56 \%$ of the variation in this trait is explained by this model (Table 7). As far as the three other cultivars are concerned, grain storage time contributed to a slightly higher rate of increase in the hardness index, with the coefficient of determination ranging from 0.69 to 0.73 .

Grain mycotoxin content: Analyzing the results of the investigation of the mycotoxin content in spring wheat grain (coefficients of deviation from the initial content in the harvest year), we conclude that the raw material proved to be safe and good (Table 8). The content of individual mycotoxins did not exceed the levels that make grain suitable for both animal feed and food purposes (Commission Regulation (EC) No 1126/2007, Polish Nutritional Standards 2014). The significantly higher grain content of DON and NIV (after 27-month storage) resulted from the initial (in the harvest year) content of these mycotoxins (Table 3). The extension of after-harvest grain storage to 15-27 months did not cause a significant increase in mycotoxin content.

Significantly lesser and statistically similar DON, NIV and ZEA were recorded for 'Monsun' and 'Zadra'. While, a like and significantly more DON, NIV and ZEA were quantified for 'Korynta' and 'Tybalt' compared to other cultivars. Whereas, varying storage times did not differ significantly for

Table 7. Regression equations and coefficients of correlation ( $r)$ and determination $\left(R^{2}\right)$ describing the effect of grain storage time $(x)$ on changes in the technological parameters of the selected spring wheat cultivars $(y)$.

\begin{tabular}{lccc}
\hline Wheat Cultivar & Moisture & Protein & Hardness index \\
\hline Korynta & $\mathrm{y}=-0.0726-0.0215 \mathrm{x} ;$ & $\mathrm{y}=0.0808-0.0088 \mathrm{x} ;$ & $\mathrm{y}=0.0506+0.0024 \mathrm{x} ;$ \\
Monsun & $\mathrm{r}=-0.88 ; \mathrm{R}^{2}=0.78$ & $\mathrm{r}=-0.93 ; \mathrm{R}^{2}=0.86$ & $\mathrm{r}=0.75 ; \mathrm{R}^{2}=0.56$ \\
& $\mathrm{y}=-0.1506-0.0156 \mathrm{x} ;$ & $\mathrm{y}=0.0378-0.0085 \mathrm{x} ;$ & $\mathrm{y}=0.0199+0.003 \mathrm{x} ;$ \\
Tybalt & $\mathrm{r}=-0.90 ; \mathrm{R}^{2}=0.82$ & $\mathrm{r}=-0.93 ; \mathrm{R}^{2}=0.86$ & $\mathrm{r}=0.85 ; \mathrm{R}^{2}=0.72$ \\
& $\mathrm{y}=-0.0536-0.0212 \mathrm{x} ;$ & $\mathrm{y}=0.0405-0.0061 \mathrm{x} ;$ & $\mathrm{y}=0.0326+0.0034 \mathrm{x} ;$ \\
Zadra & $\mathrm{r}=-0.89 ; \mathrm{R}^{2}=0.80$ & $\mathrm{r}=-0.89 ; \mathrm{R}^{2}=0.78$ & $\mathrm{r}=0.83 ; \mathrm{R}^{2}=0.69$ \\
& $\mathrm{y}=-0.1317-0.0185 \mathrm{x} ;$ & $\mathrm{y}=0.0269-0.0072 \mathrm{x} ;$ & $\mathrm{y}=0.0098+0.0035 \mathrm{x} ;$ \\
& $\mathrm{r}=-0.87 ; \mathrm{R}^{2}=0.77$ & $\mathrm{r}=-0.95 ; \mathrm{R}^{2}=0.90$ & $\mathrm{r}=0.86 ; \mathrm{R}^{2}=0.73$ \\
\hline
\end{tabular}

Table 8. Mycotoxin content in the spring wheat grain samples analyzed (mycotoxin concentration $\boldsymbol{\mu g ~ k g}^{-1} \mathrm{grain}$ ).

\begin{tabular}{|c|c|c|c|c|c|}
\hline \multirow[t]{3}{*}{ Specification } & \multicolumn{5}{|c|}{ Mycotoxins } \\
\hline & DON $^{*}$ & NIV & T2 & HT2 & ZEA \\
\hline & \multicolumn{5}{|c|}{$\begin{array}{l}\text { Storage time after harvest (months) and the mycotoxin content different (MD) of the results for } \\
\text { the individual storage times as determined after grain harvest in a particular year }\end{array}$} \\
\hline 27 & 29.8 & 3.49 & 1.18 & 2.81 & 7.24 \\
\hline $\mathrm{MD}+/-$ & +1.0 & +0.06 & +0.02 & +0.03 & +0.07 \\
\hline 15 & 24.2 & 3.09 & 1.11 & 2.76 & 7.19 \\
\hline $\mathrm{MD}+/-$ & +0.9 & +0.05 & +0.01 & +0.01 & +0.07 \\
\hline 3 & 23.7 & 2.88 & 1.09 & 2.65 & 7.14 \\
\hline MD +/- & +0.8 & +0.04 & +0.01 & +0.02 & +0.05 \\
\hline $\operatorname{LSD}_{(0.05)}$ & 5.38 & 0.392 & $\mathrm{NS}^{* *}$ & NS & NS \\
\hline \multicolumn{6}{|c|}{$\begin{array}{l}\text { Mycotoxin content different (MD) of the results for grain of the particular wheat cultivars from the individual storage times as } \\
\text { determined after grain harvest in a particular year }\end{array}$} \\
\hline Korynta & 23.4 & 2.84 & 1.06 & 2.63 & 6.86 \\
\hline $\mathrm{MD}+/-$ & +0.5 & +0.03 & +0.01 & +0.02 & +0.04 \\
\hline Monsun & 28.6 & 3.40 & 1.11 & 2.79 & 7.26 \\
\hline MD +/- & +1.1 & +0.08 & +0.02 & +0.03 & +0.09 \\
\hline Tybalt & 23.8 & 2.89 & 1.07 & 2.65 & 6.90 \\
\hline $\mathrm{MD}+/-$ & +0.6 & +0.03 & +0.01 & +0.02 & +0.04 \\
\hline Zadra & 29.2 & 3.52 & 1.14 & 2.80 & 7.31 \\
\hline $\mathrm{MD}+/-$ & +1.2 & +0.09 & +0.02 & +0.03 & +0.10 \\
\hline $\operatorname{LSD}_{(0.05)}$ & 4.725 & 0.497 & NS & NS & 0.352 \\
\hline
\end{tabular}

"Explanation: DON - deoxynivalenol, ZEA - zearalenone, NIV - nivalenol, T2 and HT2 - trichothecenes.

${ }^{* *} \mathrm{NS}$ - non-statistically significant difference 
synthesis of mycotoxins. The calculated mycotoxin content different demonstrate that this situation is due to the predisposition of the individual cultivars in relation to storage time (because in the case of the cultivars 'Zadra' and 'Monsun' MD was higher than for cvs. 'Korynta' and 'Tybalt') (Table 8).

\section{DISCUSSION}

The results of the study presented in this paper demonstrate that proper storage of wheat grain (over a period of even 3-27 months) does not contribute to a deterioration in its quality parameters. The flat warehouse used in this study had all the characteristics necessary for proper grain storage - the walls well separated from the foundation, a tight roof that provides good insulation against heat, the floor protected against moisture, an electric lighting system, equipment that enables mechanical aeration of grain. Kibar (2016) showed that if internal grain storage conditions in a warehouse are continuously controlled, there are no differences in the quality of grain stored for 0 - 90 days. A similar opinion is expressed by Linina and Ruza (2015) who studied grain stored for 60 200 days. One of the more important conditions is to maintain temperature at $10^{\circ} \mathrm{C}$. Minimal losses of components (protein) and only slight fluctuations in grain moisture content are observed at such temperature (Kibar, 2016). As shown by the results of this study, the initial grain nutrient content (determined immediately after grain harvest) is important for the quality of grain stored. Apart from agronomic practices, this quality is influenced by weather conditions during the growing season and cereal harvest. This has been proven, among others, by Champeil et al. (2004), Karaoglu et al. (2010), Strelec et al. (2010), and Linina and Ruza (2015). Rothkaehl and Abramczyk (2007) also noted that adverse weather conditions may affect the grain quality suitable for the milling industry.

Karaoglu et al. (2010) showed that regardless of storage temperature and grain moisture content, up to 3-month storage time did not result in a deterioration in the quality and technological parameters of wheat grain. Other studies have revealed that cereal grain dried to a moisture content of $14 \%$ can be bulk stored safely in warehouses for 150 weeks, i.e. for almost 3 years. The condition is to control storage humidity and temperature (Task Force Report, 2003). The above thesis was confirmed in the present study. Raza et al. (2010) proved that a decrease in flour yield was observed with increasing wheat grain storage time. Polat (2013), in turn, proved that improper storage conditions can cause a deterioration in grain quality (including a decrease in protein content) in a short time (several weeks).

Linina and Ruza (2015) stressed the role of the cultivar factor in determining the quality of grain stored. This corresponds with the results of this study - the most favorable quality parameters were found in cv. 'Korynta'. Kibar (2015), on the other hand, did not find significant differences in the response of wheat cultivars to storage time. Raza et al. (2010) observed a varied response of wheat cultivars to storage time. They found the grain moisture content to increase after 12-month storage. The reason for this was the higher humidity in the ambient environment. Erekul and Kohn (2006) as well as Jiang et al. (2009) claimed that the quality of grain of a specific wheat cultivar is genetically determined, but it is also modified to a large extent by the rainfall and temperature during plant growth and by agronomic factors

Mis et al. (2000) declared grain hardness as a very important quality characteristic. Appropriate hardness of grain determines its resistance during storage and transport. Thus, it indirectly affects other grain quality parameters (Hruskova and Svec, 2009). The present study proves that even longterm storage (27 months) of spring wheat grain in piles (when the grain storage rules were followed) did affect positively the mechanical resistance of grains as expressed by the hardness index. Apart from that, the present study demonstrated that all the spring wheat cultivars included in this study were characterized by a similar grain hardness index. The value of the grain hardness index was in agreement with the standards given by Grundas (2004).

Grains undergo huge storage loss, which is significantly due to fungal contamination; on the other hand nutrient deficiency also coexists. The spoilage mainly occurs due to moisture absorption during storage leading to fungal growth at high temperature and humidity, so, grain moisture is the key for fungal contamination to occur (Salas and Dill-Macky, 2005; Morcia et al., 2013; El-sadany et al., 2017). With low disease intensity in fungus-colonized seeds, the toxin can be produced in larger amounts during longer storage at an elevated humidity $\left(22 \%\right.$ or greater). A temperature of $22-25^{\circ} \mathrm{C}$ promotes a higher rate of zearalenone formation, about ten times higher compared to a lower temperature in the order of $12-14^{\circ} \mathrm{C}$ (Bottalico, 1998). The research conducted in Poland has not hitherto shown significant contents of zearalenone in domestic grain. Its presence was found in field-infected maize grain at an amount of $3 \mathrm{mg} \mathrm{kg}^{-1}$ (Bottalico, 1998; Chelkowski et al., 2012). On the other hand, the content of this toxin in wheat ranged from 10 to $200 \mu \mathrm{g} \mathrm{kg}^{-1}$. Most frequently, fungi producing deoxynivalenol $(\mathrm{DON}=$ vomitoxin) occur on cereal grains and diseased plants both in Poland and in other countries, which was confirmed by this study. Deoxynivalenol is produced by the species $F$. culmorum and $F$. graminearum, the same species that show the ability to synthesize zearalenone (Chelkowski et al., 2012). Hence, DON often occurs together with zearalenone (Bottalico and Perrone, 2002; Inch and Gilbert, 2003; Rocha et al., 2005; Pereyra and Dill-Macky, 2008; Lori, 2009).

Conclusions: The hypothesis adopted in the study has been confirmed. The obtained results show that storage of grain of spring wheat varieties over a period of more than 3 months 
(15-27 months) does not lead to significant negative changes in the quality characteristics of grain.

The results of this study have shown that by maintaining proper storage conditions, satisfactory technological quality of spring wheat grain (moisture content, protein content, grain hardness index, and minimal mycotoxin contamination) can be obtained during long-term (15-27 months) storage of grain compared to short-term storage (3 months).

The cultivars 'Tybalt' and 'Zadra', characterized by the lowest decline in protein content over the storage period, also had a positive effect on improving grain hardness. Grain of cvs. 'Korynta' and 'Tybalt' was characterized by lower contamination with mycotoxins than in the case of cvs. 'Monsun' and 'Zadra'.

\section{REFERENCES}

Bottalico, A. 1998. Fusarium diseases of cereals, species complex and related mycotoxin profiles in Europe. J. Plant Pathol. 80:85-103.

Bottalico, A. and G. Perrone. 2002. Toxigenic Fusarium species and mycotoxins associated with head blight in small grain cereals in Europe. Eur. J. Plant Pathol. 108:611-624.

Calucci, L., A. Capocchi, L. Galleschi, S. Ghiringhelli C. Pinzino, F. Saviozzi and Zandomeneghi. 2004. Antioxidants, free radicals, storage proteins, puroindolines, and M. proteolytic activities in bread wheat (Triticum aestivum) seeds during accelerated aging. J. Agr. Food Chem. 52:4247-4281.

Champeil, A., T. Dore and J.F. Fourbet. 2004. Fusarium head blight: epidemiological origin of the effects of cultural practices on head blight attacks and the production of mycotoxins by Fusarium in wheat grains. Plant Sci. 166:1389-1415.

Chelkowski, J., K. Gromadzka, Ł. Stępień, L. Lenc, M. Kostecki and F. Berthiller. 2012. Fusarium species, zearalenone and deoxynivalenol content in preharvest wheat heads from Poland. World Mycotoxin J. 5:133141.

El-sadany, M., G. Hosny, M. Abd Elmottaleb and H. Abou Gharbiac. 2017. Fortification of wheat grains during storage against fungal contamination of aflatoxins by coating seeds with zein-zinc coordination complex. Int. J. Environ. Sci. Toxic. Res. 5:63-73.

European Commission (EC) 2007. Commission regulation (EC) No 1126/2007 of 28 September 2007 amending Regulation (EC) No 1881/2006 setting maximum levels for certain contaminants in foodstuffs as regards Fusarium toxins in maize and maize products. Off. J. Eur. Union L. 255:14-17.

Daniel, C. and E. Triboi. 2002. Changes in wheat protein aggregation during grain development: Effects of temperatures and water stress. Eur. J. Agron. 16:1-12.
Edwards, S.G. 2004. Influence of agricultural practices on Fusarium infection of cereals and subsequent contamination of grain by trichothecene mycotoxins. Toxicol. Lett. 153:29-35.

Erekul, O. and W. Köhn. 2006. Effect of weather and soil conditions on yield components and bread-making quality of winter wheat (Triticum aestivum L.) and winter triticale (Triticosecale Wittm.) varieties in North-East Germany. J. Agron. Crop Sci. 192:452-464.

Fernandez, M.R., R.P. Zentner, R.M. DePauw, D. Gehl and F.C. Stevenson. 2007. Impacts of crop production factors on Fusarium head blight in barley in eastern Saskatchewan. Crop Sci. 45:1574-1584.

Goswami, R.S. and H.C. Kistler. 2004. Heading for a disaster: Fusarium graminearum on cereal crops. Mol. Plant Pathol. 5:515-525.

Gromadzka, K., J. Chełkowski, L. Stępień and P. Goliński. 2008. Occurrence of zearalenone in wheat and maize grain in Poland. Cereal Res. Commun. 36B:361-363.

Grundas, S. 2004. Physical characteristics of kernels in heads of common wheat Triticum aestivum L. Acta Agrophys. Rozprawy i Monografie 2:7-64.

Hruškova, M. and I. Svec. 2009. Wheat hardness in relation to other quality factors. Czech J. Food Sci. 27:240-248.

Inch, S. and J. Gilbert. 2003. The incidence of Fusarium species recovered from inflorescences of wild grasses in southern Manitoba. Can. J. Plant Pathol. 25:379-383.

Jiang, D., H. Yue, B. Wollenweber, W. Tan, H. Mu, Y. Bo, T. Dai, Q. Jing and W. Cao. 2009. Effects of PostAnthesis drought and waterlogging on accumulation of high-molecular-weight glutenin subunits and glutenin macropolymers content in wheat grain. J. Agron. Crop Sci. 195:89-97.

Karaoğlu, M.M., M. Aydeniz, H.G. Kotancilar and K.E. Gerçelaslan. 2010. A comparison of the functional characteristics of wheat stored as grain with wheat stored in spike form. Int. J. Food Sci. Technol. 45:38-47.

Kibar, H. 2015. Influence of storage conditions on the quality properties of wheat varieties. J. Stored Prod. Res. 62:815.

Kibar, H. 2016. Determining the functional characteristics of wheat and corn grains depending on storage time and temperature. J. Food Process. Preserv. 40:749-759.

Kumar, D., P. Kalita and M. Kumar. 2017. Reducing postharvest losses during storage of grain crops to strengthen food security in developing countries. Foods 6:8-14.

Linina, A. and A. Ruza. 2015. Weather conditions effect on fresh and stored winter wheat grain gluten quantity and quality. NJF $25^{\circ}$ Congress. Nordic View to Sustainable Rural Development. Crop Science and Production. June 16-18, 2015; pp.148-153.

Lori, G.A., M.N. Sisterna, S.J. Sarandon, I. Rizzo and H. Chidichimo. 2009. Fusarium head blight in wheat: 
Impact of tillage and other agronomic practices under natural infection. Crop Protec. 28:495-502.

Mis, A., S. Grundas and M. Geodecki. 2000. Changes in hardness and thickness of wheat grain as result of its moistening. Int. Agrophys. 14:203-206.

Morcia, C., E. Rattottia, A.M. Stancab, G. Tuminob, V. Rossic, S. Ravagliad, C.U. Germeiere, M. Herrmanne, I. Polisenskaf and V. Terzia. 2013. Fusarium genetic traceability: Role for mycotoxin control in small grain cereals agro-food chains. J. Cereal Sci. 57:175-182.

Pereyra, S.A. and R. Dill-Macky. 2008. Colonization of the residues of diverse plant species by Gibberella zeae and their contribution to Fusarium head blight inoculum. Plant Dis. 92:800-807.

Polat, H.E. 2013. Integration the effects of different storage types on nutritional quality characteristics of some feedstuffs. J. Food Agric. Environ. 11:897-903.

Rocha, O., K.I. Ansari and F.M. Doohan. 2005. Effects of trichothecene mycotoxins on eukaryotic cells: a review. Food Additiv. Contam. 22:369-378.

Raza, S., S. Khalil, K. Naseem, M.A. Gilani, M. Amjad, R. Maqsood and S.M.S. Naqvi. 2010. Effect of household storage receptacles on physico-chemical characteristics of wheat. Sarhad J. Agric. 26:275-287.

Rothkaehl, J. and D. Abramczyk. 2007. The technological value of wheat cultivars grown in Poland. Przegląd Zbożowo-Młynarski 8:2-4.

Rudziński, R. 2011. Rules for storage and warehousing of goods of agricultural origin. Zeszyty Naukowe UP-H w Siedlcach, Nr 88 Seria: Administracja i Zarządzanie; pp.113-126.

Salas, B. and R. Dill-Macky. 2005. Colonization of wheat cultivars by Fusarium graminearum at harvest and in overwintered residues. Proceedings of the 2005 National Fusarium Head Blight Forum Milwaukee, Wisconsin 1113 December; pp.140-143.

Strelec, I., R. Popovic, I. Ivanisic, V. Jurkovic, Z. Jurkovic, Z. Ugarcic-Hardi and M. Sabo. 2010. Influence of temperature and relative humidity on grain moisture, germination and vigour of three wheat cultivars during one year storage. Poljoprivreda 16:20-24.

Task Force Report. 2003. Mycotoxins: Risks in plant, animal, and human systems. Council for Agricultural Science and Technology, Ames, Iowa, USA. 